Dr. O. Sedlaczek
Diagnostische und
Interventionelle Radiologie,
Universitätsklinik Heidelberg,
Im Neuenheimer Feld 110,
69120 Heidelberg
oliver.sedlaczek@
med.uni-heidelberg.de

Interessenkonflikt. Der korrespondierende Autor gibt für sich und seine Koautoren an, dass kein Interessenkonflikt besteht.

\section{Literatur}

1. Amar S, Wu KJ, Tan WW (2007) Sorafenib-induced pancreatitis. Mayo Clinic Proc 82:521

2. Asnacios A, Naveau S, Perlemutter G (2009) Gastrointestinal toxicities of novel agents in cancer therapy. Eur J Cancer 45(Suppl 1):332-342

3. Baluna R, Vitetta ES (1997) Vascular leak syndrome: a side effect of immunotherapy. Immunopharmacology 37:117-132

4. Dasanu CA (2008) Gemcitabine: vascular toxicity and prothrombotic potential. Expert Opin Drug Saf 7:703-716

5. Davidson MB, Thakkar S, Hix JK et al (2004) Pathophysiology, clinical consequences, and treatment of tumor lysis syndrome. Am J Med 116:546-554

6. Duran I, Siu LL, Oza AM et al (2006) Characterisation of the lung toxicity of the cell cycle inhibitor temsirolimus. Eur J Cancer 42:1875-1880

7. Ferrans VJ (1978) Overview of cardiac pathology in relation to anthracycline cardiotoxicity. Cancer Treat Rep 62:955-961

8. Galm O, Fabry U, Adam G, Osieka R (2001) Pneumatosis intestinalis following cytotoxic or immunosuppressive treatment. Digestion 64:128-132

9. Gentilucci UV, Santini D, Vincenzi B et al (2006) Chemotherapy-induced steatohepatitis in colorectal cancer patients. J Clin Oncol 24:5467

10. Harandi AA, Zaidi S, Stocker AM, Laber DA (2009) Clinical efficacy and toxicity of anti-EGFR therapy in common cancers. J Oncol 2009:567486

11. Hurwitz RL, Mahoney DH, Armstrong DL, Browder TM (1988) Reversible encephalopathy and seizures as a result of conventional vincristine administration. Med Pediatr Oncol 16:216-219

12. Johnson $D H$, Fehrenbacher L, Novotny WF et al (2004) Randomized phase II trial comparing bevacizumab plus carboplatin and paclitaxel with carboplatin and paclitaxel alone in previously untreated locally advanced or metastatic non-small-cell lung cancer. J Clin Oncol 22:2184-2191

13. Kung D, Ruan DT, Chan RK et al (2008) Pneumatosis intestinalis and portal venous gas without bowel ischemia in a patient treated with irinotecan and cisplatin. Dig Dis Sci 53:217-219

14. Lipshultz SE, Colan SD, Gelber RD et al (1991) Late cardiac effects of doxorubicin therapy for acute lymphoblastic leukemia in childhood. $\mathrm{N}$ Engl J Med 324:808-815

15. Meadors M, Floyd J, Perry MC (2006) Pulmonary toxicity of chemotherapy. Semin Oncol 33:98-105

16. Minotti G, Menna P, Salvatorelli E et al (2004) Anthracyclines: molecular advances and pharmacologic developments in antitumor activity and cardiotoxicity. Pharmacol Rev 56:185-229
17. Oberholzer K, Kunz RP, Dittrich M, Thelen M (2004) Anthracycline-induced cardiotoxicity: cardiac MRI after treatment for childhood cancer. Rofo 176:1245-1250

18. Quinn CT, Griener JC, Bottiglieri T et al (1997) Elevation of homocysteine and excitatory amino acid neurotransmitters in the CSF of children who receive methotrexate for the treatment of cancer. J Clin Oncol 15:2800-2806

19. Rosenberg RF, Caridi JG (1983) Vincristine-induced megacolon. Gastrointest Radiol 8:71-73

20. Roychowdhury S, Maldjian JA, Galetta SL, Grossman RI (1998) Postanoxic encephalopathy: diffusion MR findings. J Comput Assist Tomogr 22:992994

21. Sandler AB, Schiller JH, Gray R et al (2009) Retrospective evaluation of the clinical and radiographic risk factors associated with severe pulmonary hemorrhage in first-line advanced, unresectable non-small-cell lung cancer treated with Carboplatin and Paclitaxel plus bevacizumab. J Clin Oncol 27:1405-1412

22. Shehata N, Pater A, Tang SC (1999) Prolonged severe 5 -fluorouracil-associated neurotoxicity in a patient with dihydropyrimidine dehydrogenase deficiency. Cancer Invest 17:201-205

23. St Peter SD, Abbas MA, Kelly KA (2003) The spectrum of pneumatosis intestinalis. Arch Surg 138:68-75

24. Steinherz LJ, Steinherz PG, Tan CT et al (1991) Cardiac toxicity 4 to 20 years after completing anthracycline therapy. JAMA 266:1672-1677

25. Tannapfel A, Geissler F, Witzigmann $\mathrm{H}$ et al (2001) Analysis of liver allograft rejection related genes using cDNA-microarrays in liver allograft specimen. Transplant Proc 33:3283-3284

26. Vahid B, Marik PE (2008) Pulmonary complications of novel antineoplastic agents for solid tumors. Chest 133:528-538

27. Verstappen CC, Heimans JJ, Hoekman K, Postma TJ (2003) Neurotoxic complications of chemotherapy in patients with cancer: clinical signs and optimal management. Drugs 63:1549-1563

28. Von Hoff DD, Rozencweig M, Layard M, Slavik M, Muggia FM (1977) Daunomycin-induced cardiotoxicity in children and adults. A review of 110 cases. Am J Med 62:200-208

29. Widakowich C, Castro G de Jr, de Azambuja E (2007) Review: side effects of approved molecular targeted therapies in solid cancers. Oncologist 12:1443-1455

30. Wiesner W, Mortele KJ, Glickman JN, Ji H, Ros PR (2001) Pneumatosis intestinalis and portomesenteric venous gas in intestinal ischemia: correlation of CT findings with severity of ischemia and clinical outcome. AJR Am J Roentgenol 177:1319-1323

31. Zamani R, Heldmann M (2004) Enteritis as a complication of adjuvant combination chemotherapy using 5-fluorouracil and leukovorin: clinical and helical computed tomographic features. J La State Med Soc 156:143-144

32. Zivkovic AM, German JB, Sanyal AJ (2007) Comparative review of diets for the metabolic syndrome: implications for nonalcoholic fatty liver disease. Am J Clin Nutr 86:285-300

Radiologe 2013 $\cdot 53: 335$

DOI 10.1007/s00117-013-2487-4

Online publiziert: 18. April 2013

(c) Springer-Verlag Berlin Heidelberg 2013

M. Gutberlet ${ }^{1} \cdot$ C. Lücke ${ }^{1}$

C. Krieghoff ${ }^{1} \cdot$ L. Hildebrand ${ }^{1}$

P. Lurz ${ }^{2}$. J. Steiner ${ }^{1} \cdot$ J. Adam $^{1}$

I. Eitel $^{2} \cdot$ H. Thiele $^{2} \cdot$ M. Grothoff $^{1}$

L. Lehmkuhl'

${ }^{1}$ Abteilung für Diagnostische und

Interventionelle Radiologie, Herzzentrum,

Universität Leipzig, Leipzig

${ }^{2}$ Abteilung Kardiologie, Herzzentrum,

Universität Leipzig, Leipzig

\title{
Erratum zu: MRT bei Myokarditis
}

\section{Radiologe (2013) 53:30-37 http://dx.doi.org/10.1007/ s00117-012-2385-1}

Im oben genannten Beitrag wurde in der Autorenzeile der Nachname von Herrn PD Dr. M. Grothoff fehlerhaft wiedergegeben. Wir bitten um Beachtung der hier korrekt aufgeführten Schreibweise.

Die Redaktion

\section{Korrespondenzadresse}

\section{Prof. Dr. M. Gutberlet}

Abteilung für Diagnostische und Interventionelle Radiologie, Herzzentrum, Universität Leipzig,

Strümpellstr. 39, 04289 Leipzig

matthias.gutberlet@herzzentrum-leipzig.de 